\title{
Tipologi intelektual Muslim dalam bidang kajian fikih: studi terhadap karya-karya fikih dosen STAIN Bengkulu
}

\author{
Sirajuddin M \\ STAIN Bengkulu \\ sirajuddin.bkl@gmail.com
}

This study aims to examine the scientific trend of approach and theme of lecturer's works of STAIN Bengkulu in the field of Islamic law $(f i q h)$ and the scientific position of lecturer's works of STAIN Bengkulu as Muslim intellectuals. This article is using two approaches, namely the conceptual approach and historical approaches, whereas measures of research was conducted by reviewing documentation as primer data and interviewing as sekunder data. The results showed that the scientific trend of approach and theme of lecturer's works of STAIN Bengkulu was consists of three kinds: First, the normative trend of scientific approach and theme in Islamic law. This trend was categorized as "exclusive Muslim intellectualism". Second, this trend began to expand the discourse of study on fikih, but it was not to integrate with Western scientific approach. This trend was categorized as "inclusive Muslim intellectualism". Third, this study was more empirical and historical-sociological approach and theme in Islamic law (fikib) so that the discourse was more be able to answer the situation and condition of the people. This trend was categorized as "pluralist Muslim intellectualism".

Tulisan ini bertujuan mengkaji kecenderungan pendekatan dan tema kajian keilmuan dosen STAIN Bengkulu dalam bidang fikih dan kedudukan karya-karya dosen STAIN Bengkulu sebagai intelektual Muslim. Pendekatan kajian menggunakan pendekatan konseptual (conceptual approach) dan pendekatan sejarah (bistorical approach), sedangkan langkah-langkah kajian dilakukan dengan melakukan kajian dokumentasi sebagai data primer dan wawancara sebagai data sekundernya. Hasil kajian menunjukkan bahwa kecenderungan pendekatan dan tema kajian fikih dosen STAIN Bengkulu terdiri atas tiga macam: Pertama, kecenderungan dari segi pendekatannya bersifat normatif, sedangkan dari segi temanya juga bersifat normatif. Kecenderungan ini masuk kategori “intelektualisme Muslim ekslusif”. Kedua, kencederungan ini mulai memperluas wacana kajian fikih, tetapi tidak sampai mengintegrasikan dengan pendekatan sains Barat. Kecenderungan ini kategori “intelektualisme Muslim inklusif”. Ketiga, kajian fikih ini lebih bersifat empiris dan historis- 
ljtihad, Jurnal Wacana Hukum Islam dan Kemanusiaan, Vol. 12, No. 2, Desember 2012: 237-258

sosiologis, sehingga wacana fiqih ini lebih mampu menjawab perkembangan situasi dan kondisi umat. Kecenderungan ini masuk kategori "intelektualisme Muslim pluralis".

Keywords: Trends; Fiqh; Islamic intellectualism; Islamic law

\section{Pendahuluan}

Hasil kajian Azyumardi Azra menyebutkan bahwa pembentukan perguruan tinggi Islam secara umum didorong oleh setidaknya tiga tujuan: Pertama, untuk melaksanakan pengkajian dan pengembangan ilmu-ilmu agama Islam pada tingkat yang lebih tinggi secara lebih sistematis dan terarah. Kedua, untuk melakukan pengembangan dan peningkatan dakwah Islam, sehingga Islam dipahami dan dilaksanakan secara lebih baik oleh mahasiswa dan kaum Muslim umumnya. Ketiga, untuk melakukan reproduksi dan kaderisasi ulama dan fungsionaris keagamaan lainnya, baik pada birokrasi Negara, seperti Kementerian Agama ataupun lembaga-lembaga sosial, dakwah dan pendidikan Islam swasta (Azra, 1999: 170)

Dalam dasawarsa awal perkembangan Institut Agama Islam Negeri (IAIN), kajiankajian tentang ilmu-ilmu agama Islam di IAIN memiliki tiga kecenderungan. Pertama, wacana keilmuan dosen yang bersifat normatif-idealistik. Kedua, wacana keilmuan dosen yang berorientasi pada sektarianisme mazhab, khususnya mazhab Syafi'i dan kalam Asy'arie. Ketiga, wacana keilmuan dosen yang berkiblat kepada paradigma kajian keagamaan Timur Tengah. Keempat, wacana keilmuan dosen yang terpencil atau terpisah dari perkembangan sains dan ilmu pengetahuan pada umumnya (Azra, 1999: 170).

Sejak tahun 1970 ke belakang telah terjadi pengembangan dan perubahan terhadap IAIN dengan tampilnya sejumlah tokoh pembaru Islam, seperti Nourcholish Madjid, A Mukti Ali, dan Harun Nasution, yang kemudian menyebabkan timbulnya perubahan penting terhadap wacana kajian ilmu-ilmu agama Islam di IAIN. Perubahan-perubahan kajian ilmuilmu agama Islam itu memiliki tiga kecenderungan: Pertama adalah kajian-kajian Islam yang bersifat non-mazhab atau menggunakan pendekatan non-mazhab. Hal ini sangat berbeda dengan kecenderungan umat Islam pada umumnya yang bermazhab Syafi'i, sehingga kecenderungan ini lebih rasional dan ilmiah, tidak apologetik. Kedua mulai ada pergeseran paradigm kajian ilmu-ilmu agama Islam dari yang bersifat normatif kepada yang bersifat historis, sosiologis dan empiris. Pendekatan normatif melahirkan pandangan yang serba 
idealistik terhadap Islam, sedangkan pendekatan historis dan sosiologis membuka cakrawala dalam membaca realitas riil dan mampu menjawab perkembangan serta perubahan yang terjadi di masyarakat. Ketiga adalah orientasi keilmuan yang lebih luas. Dalam konteks ini, pendekatan Barat mulai digunakan dalam mengkaji ilmu-ilmu agama Islam seiring dengan mulai datangnya para intelektual dari Barat, tamatan McGill University ataupun universitas di Amerika (Azra, 1999: 171).

Walaupun semakin tahun, semakin meningkat kencenderungannya ke arah kajian ilmuilmu agama Islam yang berbasis empiris dan sainstifik Barat, tetapi hasil pengamatan Imam Suprayogo, Rektor UIN Maulana Malik Ibrahim Malang, justru berpendapat sebaliknya. Ia menyebutkan bahwa dari berbagai statemen yang diikuti, Nur Syam telah mengungkapkan kegelisahannya terhadap melemahnya kajian ilmu-ilmu agama Islamdi Indonesia. Bahkan ada sebagian intelektual Muslim yang kurang mengapresiasi pengembangan ilmu-ilmu agama Islam. Keprihatinan yang sama juga diungkap oleh Abd A’la. Ia menjelaskan bahwa posisi kajian ilmu-ilmu agama Islam pada dasarnya sangat penting, tetapi faktanya kurang tidak mendapat perhatian dan bahkan dianggap tidak jelas lagi. Ilmu agama hanya dipandang sebagai bagian ilmu sosial dan humaniora. Kenyataan ini terasa aneh. Sebab, di negeri ini, institusi yang memiliki tangggung jawab mengembangkan ilmu agama, jumlahnya cukup banyak. PTAIN itu tersebar di seluruh Indonesia, mulai dari Aceh hingga Papua, belum PTAIS. Semua perguruan tinggi Islam tersebut memiliki misi pokok melakukan kajian dan pengembangan ilmu agama Islam. Oleh karena itu, jika akhir-akhir ini dirasakan misi pokok itu tidak berjalan maksimal dan bahkan sementara pihak tidak mengapresiasi, maka problem ini perlu mendapat perhatian semua kalangan. Sebab, kajian ilmu-ilmu agama Islam merupakan tanggung jawab utamanya, yang kemudian diperluas dengan wacana ilmu-ilmu sains modern atau kontemporer. Perubahan itu penting agar perkembangan ilmu-ilmu agama Islam bisa berjalan seirama dengan perkembangan fisik gedungnya. Perkembangan fisik PTAIN pada akhir-akhir ini mengalami kemajuan yang luar biasa. Bangunan fisik PTAIN, baik UIN, IAIN maupun STAIN mengalami kemajuan yang amat pesat. Hampir setiap PTAIN pada saat sekarang ini memiliki wajah yang jauh berbeda dibanding sepuluh tahun sebelumnya (Suprayogo, 2012). Salah satu PTAIN yang terus berbenah diri secara fisik dan telah menaikkan statusnya adalah STAIN Bengkulu menjadi IAIN Bengkulu. 
STAIN Bengkulu pada awalnya cabang dari IAIN Raden Fatah Palembang, seiring dengan perkembangan waktu, maka pada tahun 2007, semua fakultas cabang IAIN yang berada di daerah dijadikan STAIN. STAIN Bengkulu pada awalnya adalah Fakultas Syariah kemudian menyusul Fakultas Tarbiyah IAIN Raden Fatah di Bengkulu. Pada saat ini, STAIN Bengkulu sudah menjadi IAIN Bengkulu tahun 2012 berdasarkan Peraturan Presiden tahun 2012. Karena STAIN Bengkulu pada awalnya adalah Fakultas Syariah IAIN Raden Fatah di Bengkulu tentunya wacana ilmu-ilmu agama Islam dalam bidang fiqih lebih banyak daripada kajian-kajian keilmuan lainnya. Oleh sebab itu, kajian ini bertujuan mengkaji kecenderungan kajian keilmuan dosen STAIN Bengkulu dalam bidang fikih.

Kajian keilmuan fikih di perguruan tinggi tidak hanya dilakukan saat ini saja, tetapi para ilmuwan sebelumnya sudah ada yang melakukan penelitian yang hampir sama, misalnya karya Azyumardi Azra, Cendekiawan Muslim Indonesia, yang kemudian dijadikan kerangka teori dalam tulisan ini. Ia telah memetakan kecenderungan arah kajian dan materi keilmuan agama para dosen IAIN, tetapi kajian Azra masih bersifat umum, belum spesifik terhadap tema tertentu (Azra, 1999: 16).

Karya tulis Rahimin Affandi Abd. Rahim dkk telah melakukan kajian terhadap bidang keilmuan fikih di Malaysia. Tulisan ini mengungkapkan bahwa kajian fikih ini ber sifat dinamik konsep fikih dalam sistem perundangan Islam Malaysia yang menekankan kepentingan hubungan dengan Allah dan sesama makhluk. Teori yang digunakan di sini adalah teori epistemologi hukum Islam yang menetapkan bahwa sifat kelestarian sistem hukum Islam hanya boleh dicapai melalui jalan pembentukan kerangka epistemologi. Hasil kajian ini menunjukkan bahwa konsep fikih telah dipahami oleh masyarakat Malaysia, tetapi masih perlu pemantapan konsep fikih dalam kehidupan masa kini, yang hal ini seharusnya dilakukan pihak Institusi Pengajian Tinggi Awam (IPTA) di Malaysia (Rahim dkk, 2010).

Gamal Abdul Nasir Hj Zakaria dan Salwa Dato Hj Mahalle, dosen Universiti Brunei Darussalam, juga melakukan penelitian berjudul "The Role of I.A.I.N. In The Education System Reform of the "Madrasah". IAIN adalah salah satu bagian dari sistem pendidikan Islam di Indonesia. Sebagai lembaga pendidikan tinggi Islam, IAIN adalah lembaga lanjutan dari Madrasah Aliyah. Pendirian madrasah dimaksudkan untuk menyediakan pendidikan Islam. Sebagai salah satu bagian dari sistem pendidikan Islam, IAIN memiliki hubungan 
sangat erat dengan madrasah dan pesantren. Sejak tahun 1980-an, IAIN telah memiliki peranan penting dalam pengembangan dan reformasi sistem pendidikan madrasah dan pesantren. Peran IAIN tidak hanya terbatas menyediakan guru agama sebagaimana masa awal pendiriannya, IAIN sekarang dapat memberikan sumbangan terhadap pemahaman dan interpretasi yang kontekstual terhadap ajaran Islam (Mahalle, 2012).

Karya Nur A. Fadhil Lubis, Pengembangan Studi Hukum Islam Di IAIN, http:// www.ditpertais.net/artikel/fadil01.asp diakses 12 sep 2012 mengungkapkan bahwa yang menjadi obyek dan ruang lingkup studi di IAIN mencakup tiga bidang pokok. Pertama, studi hukum Islam sebagai ajaran, yang terwujud dalam bentuk wahyu Ilahi yang terhimpun dalam al-Qur'an dan Sunnah, yakni panduan Rasulullah saw. bagi umatnya yang terhimpun dalam hadist. Ilmu-ilmu ini, sejak beberapa waktu yang lalu menjadi jurusan Tafsir-Hadist di Fakultas Ushuluddin dan merupakan program studi khusus pada tingkat pascasajrana. Kedua, studi Islam juga dikaji sebagai bagian dari pemikiran, sebagai bagian dari fikih dalam arti luas, sebagaimana diperintahkan Allah swt. Dalam sejarah perkembangan pemikiran Islam (Islamic thought) terlihat ada lima bidang pemikiran Islam yang menojol, yaitu: akidahteologi ('ilm al-kalām), hukum dalam arti luas (shari’ah), filsafat (hikmah/'irfan/falsafah), akhlak-sufisme (tașawwuf). Ketiga, studi Islam pada tingkat berikutnya merupakan pengalaman dan penerapannya dalam kehidupan. Bersumberkan pada al-Qur'an dan Sunnah yang dijabarkan dalam berbagai pemikiran, ajaran Islam kemudian diamalkan dan diterapkan oleh umat Islam hingga membentuk peradaban Islam yang telah berabad-abad menyinari dunia. Islam sebagai pengalaman yang menonjol dikaji dan dikembangkan IAIN selama ini adalah aspek pendidikan (tarbiyah), dakwah dan tentu saja hukum (Lubis, 2012).

Dadi Darmadi dalam IAIN dalam Wacana Intelektual Islam Indonesia, http:// www.ditpertais.net/artikel/dadi01.asp diakses 12 September 2012 menyebutkan bahwa selama hampir lebih dari tiga puluh tahun, IAIN telah memainkan peran penting di dalam pengembangan dan pembaharuan sistem pendidikan Islam di Indonesia, khususnya pada pendidikan madrasah dan pesantren. Peran penting ini dapat dilihat bukan hanya terbatas pada penyediakan guru-guru bagi kalangan pelajar Muslim tetapi -dan ini yang lebih pentingIAIN telah memengaruhi cara pandang, pemahaman dan penafsiran Islam yang lebih luas dan terbuka. Sebagai lembaga pendidikan Islam tertinggi di Indonesia, IAIN telah menjadi 
salah satu harapan terbaik bagi komunitas Muslim yang ingin mengkaji Islam setelah mereka menamatkan bangku Madrasah Aliyah atau pesantren. IAIN menjadi satu-satunya tempat pengembangan intelektual muda dan aktifis Muslim (Darmadi, 2012).

Dari uraian tersebut, dapat dinyatakan bahwa tulisan ini belum pernah diteliti oleh penulis sebelumnya, terutama yang berhubungan dengan pokok masalah penelitian mengenai latarbekang dan kecenderungan pendekatan dan tema kajian karya-karya fikih dosen STAIN Bengkulu. Dari pokok masalah tersebut dirumuskan pertanyaan berikut, apakah yang melatarbelakangi lahirnya kecenderungan pendekatan dan tema kajian keilmuan fikih dosen STAIN Bengkulu? Bagaimana kecenderungan pendekatan dan tema kajian keilmuan fikih dibangun oleh dosen STAIN Bengkulu? Oleh sebab itu, tujuan kajian ini fokus pada dua permasalahan tersebut.

Adapun pendekatan kajian yang digunakan ini adalah pendekatan konseptual (conceptual approach) dalam telaah konsep yang berkenaan dengan masalah-masalah hukum Islam/fikih yang ada dalam karya-karya dosen STAIN Bengkulu. Pendekatan sejarah (historical approach) digunakan dalam menelaah latarbelakang lahirnya karya-karya fikih dosen STAIN Bengkulu. Penulisan kajian ini dilakukan mulai dari kajian dokumentasi sebagai sumber primer dan wawancara sebagai sumber sekundernya (Lincoln, 2009: 307), sedangkan metode analisis bahan yang digunakan adalah analisis kualitatif.

\section{Kerangka teori}

Kecenderungan pertama yang paling dapat diamati adalah bahwa kajian-kajian tentang ilmuilmu agama Islam di STAIN/IAIN pada umumnya bersifat non-mazhab atau menggunakan pendekatan non-mazhab. Dalam pendekatan ini, kajian-kajian keilmuan agama Islam dalam berbagai bidang seperti fikih (hukum), kalam, filsafat Islam, sufisme dan tarekat cenderung tidak lagi memihak kepada salah satu mazhab atau aliran tertentu. Pendekatan kajian-kajian tentang ilmu-ilmu agama Islam cenderung lebih obyektif atau eksposisi “ilmiah" tentang berbagai mazhab dan aliran yang tumbuh dan berkembang dalam Islam tanpa keharusan untuk memilih atau mengikuti mazhab atau aliran tertentu yang sudah mapan. Sebagaimana diketahui terdapat banyak mazhab dan aliran pemikiran dalam Islam, kaum Muslimin Indonesia umumnya menjadi pengikut Sunni, yang dalam bidang fikih mengikuti mazhab 
Syafi'i. Dalam pendekatan non-mazhabi, kajian-kajian terhadap ilmu-ilmu agama Islam di STAIN/IAIN memberikan eksposisi dan eksplikasi terhadap seluruh mazhab fikih Sunni (Hanafi, Hanbali, Maliki, Syafi'i). Oleh sebab itu, di sini tidak diharuskan mengikuti salah satu aliran tertentu (Azra, 1999: 171).

Kecenderungan pokok kedua adalah terjadinya pergeseran dari kajian ilmu-ilmu agama Islam normatif kepada historis, sosiologis dan empiris. Pendekatan normatif dalam kajian ilmuilmu agama Islam menghasilkan wawasan keilmuan dan pandangan idealistik terhadap Islam yang telah menyebabkan kaum Muslimin lupa dalam meneliti realitas riil. Sebaliknya, pendekatan historis dan sosiologis dapat membuka cakrawala mahasiswa STAIN/IAIN dalam meneliti dan membaca perkembangan dan perubahan empiris di masyarakat (Azra, 1999: 171).

Jika dihubungkan dengan dua kecenderungan tersebut, kecenderungan pokok ketiga adalah orientasi kajian keilmuan yang lebih luas. Jika pada masa awal orientasi kajian keimuan cenderung ke Timur Tengah, khususnya Universitas al-Azhar, dalam dua dasawarsa terakhir kelihatan semakin luas dan beragam. Dalam konteks ini, pendekatan sains Barat terhadap ilmu-ilmu agama Islam mulai tumbuh dan berkembang yang cenderung lebih bersifat historis dan sosiologis. Pendekatan ini menemukan momentumnya dengan kembalinya sejumlah lulusan Universitas Barat untuk mengajar di IAIN. Mereka kembali secara bergelombang, dimulai dengan generasi A Mukti Ali (di IAIN Sunan Kalijaga Yogyakarta), Harun Nasution (IAIN Syarif Hidayatullah Jakarta) dan kemudian disusul kelompok lulusan McGill University. Gelombang berikutnya masih terus berlanjut hingga yang dikirim belajar ke beberapa Universitas Amerika pada masa Menteri Agama Munawir Sjadzali. Penting dicatat bahwa kemunculan pendekatan baru "model Barat" ini tidak serta merta sepenuhnya bisa diterima oleh kalangan STAIN/IAIN dan bahkan kaum Muslimin umumnya. Sebab, pendekatan sains Barat terhadap ilmu-ilmu agama Islam sering dituduh sebagai kajian orientalis dan kebarat-baratan (Azra, 1999: 172).

\section{Akar historis wacana intelektualisme Muslim di PTAIN}

Pengertian sederhana tentang kata "intelektual”, misalnya, dikemukakan George A. Theodorson dan Achilles G. Theodorson yang menyebutkan bahwa kaum intelektual adalah 
anggota-anggota masyarakat yang mengabdikan dirinya pada pengembangan ide-ide orisinal dan terikat dalam pencarian pemikiran-pemikiran kreatif. Sebagaimana dikatakan Lewis, pengertian ini memiliki konotasi bahwa kaum intelektual adalah setiap orang yang tidak pernah puas menerima kenyataan riil seperti apa adanya. Mereka selalu berusaha mempertanyakan kebenaran-kebenaran yang berlaku dalam hubungannya dengan kebenarankebenaran yang lebih tinggi dan luas. Karakteristik dasar ini membedakan kaum intelektual dengan anggota masyarakat pada umumnya, yaitu penggunaan intelek dan akal pikiran bukan untuk hal-hal yang bersifat praktis, tetapi lebih berorientasi pada pengembangan ideide, sehingga pengembangan sikap skeptis diperlukan untuk mempertanyakan nilai-nilai dan pikiran yang sudah mapan untuk menemukan ide-ide dan kebenaran-kebenaran baru (Azra, 1999: 157).

Osman Bakar pernah menyebutkan bahwa kaum intelektualisme Muslim dalam mengkaji berbagai permasalahan kehidupan tidak boleh bertentangan dengan nilai-nilai keislaman karena ia merupakan bagian integral dari kewajiban keagamaan. Dengan menumbuhkan dan mengembangkan ilmu-ilmu agama Islam dalam kehidupan manusia berarti telah mengupayakan penerapa ilmu-ilmu agama Islam dalam tataran aplikatif. Sikap dinamis kaum intelektualisme Muslim dapat dilihat dari kegelisahan akademik dalam mengkaji ilmu-ilmu agama Islam. Dalam sejarahnya, kaum intelektualisme Muslim kampus pada awalnya menggunakan pendekatan tradisional yang juga banyak dikembangkan di lembaga-lembaga “modelpesantren” atau "model PTAIN”. Pendekatan ini secara sederhana lebih mengutamakan peran wahyu daripada akal. Selanjutnya, pendekatan “model sekolab” atau “model PTN”yang ditengarai sebagai pendekatan modern karena lebih mengedepankan peran akal daripada wahyu. Kedua pendekatan tersebut melihat wahyu dan akal secara struktural, bukan secara fungsional. Dari kedua pendekatan tersebut, mereka akhirnya mengenalkan beberapa pendekatan: naqliyah dan aqliyah, jabariyah dan qadariyah, teologis dan antropologis, tekstual dan kontekstual, skriptural dan substansial, absolut dan relatif, normativitas dan historisitas, doktrinal dan saintifik, transenden dan empiris, kualitatif dan kuantitatif, taklid dan ijtihad, bi al-riwāajah dan bi al-ra'y, tatbiq al-shari'ah dan tajdid al-fahm atau strukturalisme transendental, eksternalisasi dan objektifikasi Islam, eksklusif dan inklusif, otoriter dan demokratis, individual dan kolektif, dan lain sebagainya (Bakar, 1994: 11-13 dan Masruri, 2010). 
Kenyatan tersebut kemudian memperkuat pandangan tentang sikap kaum intelektual Muslim yang selalu progresif dan revolusioner walaupun lebih diwujudkan dalam revolusi pemikiran, bukan revolusi fisik, sehingga wacana keilmuan kritis dari kaum intelektual berkembang subur. Sebagai kritikus dalam masyarakat, kaum intelektual Muslim menyatakan pikiran dan kritiknya secara jelas dan bijak. Dengan demikian, kaum intelektual Muslim berarti kaum yang berfikir bebas dalam artian mencakup pengamatan yang cermat terhadap gejala-gejala di lingkungannya, pemahaman tentang sebab-sebab gejala itu dan korelasinya dengan gejala lain secara utuh. Perumusan dari proses pemikiran itu kemudian dikomunikasikan dengan nilai-nilai ajaran agama Islam. Kaum intelektual Muslim di sini berbeda dengan kaum intelegensia Muslim, karena sebagai produk perguruan tinggi, mereka telah menerima pendidikan yang membuat mereka mampu memegang pekerjaan sesuai dengan bidang dan profesi ilmunya. Disamping itu, banyak pula lulusan perguruan tinggi yang mengalami kemandegan atau kehilangan kapasitas intelektualnya ketika mereka masuk ke dalam birokrasi dan rutinitas akademis di perguruan tinggi atau di manapun mereka bekerja. Produk perguruan tinggi yang diharapkan menjadi inovator atau pembaharu masyarakat kemudian terjebak dalam mekanisme birokrasi dan spesialisasi atau profesinya yang sempit. Padahal, masalah-masalah yang dihadapi masyarakat dewasa ini tidak bisa dipecahkan dengan pendekatan sempit semacam itu; pemecahan masalah sekarang ini membutuhkan pendekatan menyeluruh, inter-disipliner dan berwawasan luas (Azra, 1999: 158-159). Oleh karena itu, peran kaum inetelektual Muslim sangat penting dalam menyelesaikan berbagai permasalahan multidisipliner di masyarakat, sebab kaum intelektualisme Muslim berusaha menjawab dan menyelesaikan masalah secara utuh, tidak sempit.

Kehadiran kaum 'intelektual sekuler' atau 'intelektual baru' ini telah menimbulkan masalah, yakni terbentuknya gap antara kaum intelektual baru pada satu pihak dengan kaum intelektual lama (ulama) pada pihak lain. Kaum intelektual baru hasil pendidikan Barat cenderung terpisah dari kaum intelektual lama (ulama). Bahkan yang terakhir ini sering dikonotasikan sebagai kaum sarungan yang hanya tahu soal-soal keagamaan, tetapi buta dalam masalah-masalah keduniaan. Implikasi selanjutnya adalah terjadi penyempitan pengertian ulama, sebagai mereka yang hanya mengerti soal-soal keagamaan belaka. Sering mereka tidak dimasukkan ke dalam barisan kaum intelektual. Karena itulah, kemudian muncul gagasan di kalangan umat Islam 
ljtihad, Jurnal Wacana Hukum Islam dan Kemanusiaan, Vol. 12, No. 2, Desember 2012: 237-258

Indonesia untuk menciptakan ulama intelektual dan intelektual ulama. Dengan kata lain, agar ulama intelektual atau intelektual ulama dapat dijumpai pada diri seseorang. STAIN/IAIN/ UIN mempunyai tugas sebagai wadah penyiapan penafsir-penafsir Islam dan untuk kemudian dikomunikasikan pada masyarakat luas. Interpretasi-interpretasi baru yang diberikan terhadap ajaran-ajaran (hukum) Islam dengan demikian haruslah dapat dikomunikasikannya dengan bahasa yang jelas dan dimengerti masyarakat. Sebagai ulama yang intelek tentu harus memiliki kedalaman keilmuan agama Islam, termasuk bidang ilmu fikih (Azra, 1999: 161).

Kalau mengacu kepada tiga kecenderungan tersebut, maka kaum intelektual Muslim jika dilihat dari segi kajian keislamannya juga dapat dikategorikan menjadi tiga kelompok berdasarkan wawasan keilmuan (Alwi Shihab, 2005; Din Syamsuddin dalam Zahra, 1999; James Norman Dalrymple Anderson, 1991: 91; dan John R Bowen, 2003: 148-149). Pertama, kaum inetelektual Muslim yang hanya menerima ilmu-ilmu agama Islam tanpa sentuhan ilmu-ilmu empiris dan historis-sosiologis, sehingga gagasannya bersifat eksklusif. Kedua, kaum intelektual Muslim yang mulai membuka relasi antara ilmu-ilmu agama Islam dengan ilmu-ilmu empiris dan historis-sosiologis atau sains Barat, tetapi masih berwatak apologis jika Islam dihadapkan dengan sains Barat. Ketiga, kaum intelektual Muslim yang berusaha mensinergikan ilmu-ilmu agama Islam dengan ilmu-ilmu empris dan historissosiologis atau sains Barat, sehingga dialektika antara keduanya berjalan secara kritis dan konstruktif.

Salah satu yang patut diperhatikan adalah bidang keilmuan fikih yang merupakan fokus bahasan penting dalam ilmu agama Islam di Perguruan Tinggi Agama Islam. Karena tanpa fikih, maka seseorang akan tidak akan mampu menjalankan kewajiban keagamaannnya sebagai seorang Muslim, sehingga kajian mendalam terhadap masalah fikih penting dilakukan agar umat Islam bisa melaksanakan norma-norma fikihnya secara baik dan benar sesuai dengan perkembangan situasi dan kondisinya.

\section{Kecenderungan pendekatan dan tema kajian fikih dosen STAIN Bengkulu}

Kecenderungan eksklusif

Dalam pembahasan kecenderungan pertama ini, peneliti mengemukakan tiga tema kajian dosen STAIN Bengkulu sebagai berikut (Dahlan, 2012); Pertama, karya Alwan Khoiri (2000) 
berjudul Perkawinan Antaragama: PerspektifHukum Islam juga sama sebagaimana kajian kitabkitab fikih tradisional yang menandaskan bahwa Allah tidak menghalalkan wanita Mukminah menikah dengan pria Kafir. Alasan yang digunakan adalah bahwa jelas perbedaan antara wanita Mukminah dan suamiya yang Kafir itu. Hikmah diharamkannya wanita Muslimah menikah dengan pria non-Muslim antara lain, karena dikhawatirkan wanita tersebut akan terseret mengikuti agama suaminya. Sebagaimana diketahui bahwa wanita itu (istri) harus tunduk dan patuh kepada suaminya, karena suami adalah kepala rumah tangga, maka kekuasaan penuh berada di tangan suami. Selain itu, orang kafir tidak boleh dijadikan pemimpin bagi kaum Muslimin maupun Muslimat (QS. al-Nisā’’141) Di samping itu, seorang suami yang kafir tidak akan mengakui dan menghormati agama yang dianut oleh istrinya yang Muslimah, dan bahkan mendustakannya. Oleh karenanya, fikih tradisional tidak menghalalkan bagi wanita muslimah menikah dengan pria Kafir dan pria non-Muslim lainnya (Zainuddin, t.th dan Aibak, 2009: 46).

Hasil kajian ini menunjukkan bahwa fikih dengan tegas melarang pria Muslim menikah dengan wanita Musyrikah; fikih dengan tegas melarang wanita Muslimah menikah dengan pria Musyrik dan pria non-Muslim lainnya, termasuk pria Ablal-Kitāab; fikih membolehkan pria Muslim menikah dengan wanita Kitābiyah, antara lain dengan dua pertimbangan; antara pria Muslim dan wanita Kitābiyah mempunyai hubungan keimanan yang sangat erat, yakni sama-sama percaya kepada Allah, Risalah-risalah-Nya, Kitab-kitab-Nya, Hari Akhir, dan memiliki nilai-nilai akhlak yang sama; dan pria Muslim yang akan menikah dengan wanita Kitabiyah harus betul-betul memiliki keteguhan iman, karena jika wanita Kitabiyah hidup di bawah naungan suami Muslim yang betul-betul teguh imannya, maka wanita Kitabijah tersebut akan berperan pasif sebagai penerima pengaruh dan tidak dapat memengaruhi suaminya (Dahlan, 2012 dan Gaus AF, 2001). Pembahasan yang ada dalam ulasan ini sama dengan apa yang dipaparkan oleh ulama-ulama fikih lama (Asy-Sirazi, 1994), sehingga belum ada pembaruan yang penting dan mampu menjawab perkembangan-perkembangan aktual yang dihadapi umat, selain hanya pandangan reaksionis jika beranjak dari tema kajian fikih ini.

Kedua, karya Yen Fikri Rani (2007) berjudul Rekonstruksi Tasawuf dan Syariat: Sebuah Pemikiran Ahmad Sirbindi, menjelaskan bahwa Ahmad Sirhindi telah berhasil membangun sinergi antara pengetahuan orang awam dengan para sufi. Ia menyelesaikan masalah konsep 
waḥdat al-wujüd dengan wạ̣dat al-shubüd, yakni Tuhan itu berbeda dengan makhluknya. Untuk memecah hijab antara khalik dengan makhluk, ia menawarkan latihan qalb (hati). Walaupun demikian, tulisan ini masih mengkritik Sirhindi yang dianggapnya tertalu jauh masuk terhadap praktek sufi yang pada dasarnya tidak pas, terlebih dengan pendekatan yang berbeda, yakni pendekatan teologis. Tema kajian ini murni bersifat syariat kaitannya dengan tasawuf yang tidak ada nuansa pembaruan dan eksplorasi kaitannya dengan perkembangan situasi dan kondisi. Ia hanya menyelesaikan konflik internal antara syariat dengan tasawuf, belum memberikan ulasan yang lebih terbuka terhadap masalah aktual di bidang fikih.

Ketiga, karya Nurbaiti (2007) berjudul Implikasi Sunnah Tashri'iyyah dan Ghayr Tashri'izyah. Tema kajian fikih ini berdasarkan sumber hukum kedua, yaitu sunnah. Ia membagi sunnah menjadi dua, yaitu Sunnah Tashri'iyyah adalah segala perkataan, perbuatan dan pengakuan dari Nabi saw yang memiliki daya kekuatan hukum bagi umat Islam, sedangkan sunnah ghayr tashri'iyyah adalah segala apa yang berasal dari Nabi saw yang tidak memiliki kekuatan hukum dan tidak wajib diikuti oleh umatnya. Implikasi sunnah tashri'iyyah adalah bahwa sunnah yang datang dari Nabi dalam kapasitasnya sebagai rasul berfungsi menjelaskan dan menguatkan hukum-hukum fikih yang terkandung dalam al-Qur'an, sedangkan sunnah yang datangnya dari nabi dalam kapasitasnya sebagai kepala negara bersifat ijtihadi seperti jabatan qadi atau hakim. Tema kajian fikih ini mengulas aspek-aspek hukum yang terdapat dalam wacana keilmuan fikih dan tidak ada ulasan yang baru dari pembahasan kajian ini.

Dari beberapa tema kajian yang diulas di atas dapat dinyatakan bahwa jika dibaca dari segi pendekatannya bersifat normatif, sedangkan dari segi temanya juga normatif karena segala pembahasan yang ada dalam ulasan ini sama dengan apa yang dipaparkan oleh ulamaulama fikih lama (Abdullah, 1996). Tidak ada yang baru dari karya ini, sehingga pengempokan karya tulis ini tepat sekali sebagaimana pandangan Azyumardi Azra. Menurut pendapat Rohimin, adanya karakter pendekatan dan tema kajian yang normatif ini tidak lepas dari pengaruh tradisi kajian fikih di lingkungan IAIN di masa lampau yang sarat dengan wacana normatifnya. Pada tahun 2000, Rohimin menuturkan bahwa arus responsif pemikiran keagamaan masih belum pudar, sehingga kalangan yang tidak sepenuhnya menerima modernitas Islam sebagaimana disuarakan oleh Harun Nasution dkk, kemudian mengembangkan wacana keilmuan keagamaan Islam fundamentalis atau radikalis yang 
biasanya berbasiskan aturan literalistik-lokalistik (wawancara dengan Rohimin, guru besar STAIN Bengkulu pada tanggal 7 September 2012).

Tema kajian ini masih berkarakter sebagaimana watak awal pendidikan IAIN yang sepanjang eksistensinya berkaitan banyak dengan latar belakang pembentukan dan perkembangan IAIN itu sendiri, khususnya vis a-vis umat Islam. Kemunculan IAIN, sebagimana dikemukakan di depan, harus diakui merupakan realisasi dan aspirasi yang telah lama dimiliki umat Islam, yakni adanya perguruan tinggi agama Islam, yang merupakan kelanjutan dari pesantren dan madrasah yang telah berkembang sepanjang sejarah Islam di negeri ini. Oleh sebab itu, tema kajian fikih di PTAI juga banyak dipengaruhi wacana fikih yang berkembang di pesantren dan madrasah (Azra, 1999: 169-174).

Jika dianalisis dari konsep intelektualisme Muslim karya Azyumardi Azra, maka kategori ini masuk intelektualisme Muslim ekslusif karena tema-tema kajiannya hanya mengungkap tema-tema kajian fikih an sich tanpa sentuhan sains-sains modern dan perkembanagn wacana keilmuan modern. Nurcholis Madjid menyebutkan bahwa kaum intelektual Muslim ekslusif adalah kaum intelektual yang hanya mengapresiasi norma-norma agama/fikih Islam yang ekslusif (Bowen, 2009: 149).

\section{Kecenderungan inklusif}

Dalam ulasan ini, peneliti mengambil tiga contoh wacana keilmuan fikih dosen STAIN Bengkulu yang memiliki kecenderungan tipe kedua ini (Dahlan, 2012): Pertama, karya Syarnubie (2000) berjudul Rekonstruksi Pemikiran Format Hukum Islam. Tema kajian fikih ini memiliki cakupan relatif lebih luas, karena pembahasan zakat menurut Yusuf al-Qardhawi itu tidak hanya memuat ulasan-ulasan pendapat ulama masa lampau, tetapi juga memasukkan kasus-kasus aktual, seperti zakat profesi, jasa dan harta. Disamping itu, alternatif lain yang bisa dilakukan dalam menyusun kerangka dan sistematika fiqih di dalam bentuk undangundang, seperti kitab undang-undang yang berlaku pada masa pemerintahan Islam Turki Usmani. Di Indonesia sudah diberlakukan Kompilasi Hukum Islam (KHI), melalui Inpres Nomor I Tahun 1991. KHI ini terdiri atas Hukum Perkawinan, Kewarisan dan Perwakafan, merupakan salah satu bentuk sistematika fiqih yang telah menjadi hukum positif. Namun tentu saja, cakupannya masih sangat terbatas, terlebih bila dikaitkan dengan cakupan hukum 
Islam yang luas dan keanekaragaman kehidupan masyarakat Indonesia. Dengan demikian, sesuai dengan watak dan karakteristik yang berkembang pada setiap masa, maka fiqih memiliki sifat terbuka dan fleksibel untuk pengembangan metode selanjutnya. Oleh karena itu, tawaran sistematika fiqih sebagaimana telah disebutkan, tidaklah tertutup untuk pengembangan lebih lanjut, sesuai dengan hasil ijtihad yang ditemukan dan keragaman kehidupan yang terjadi pada masa-masa berikutnya, baik berhubungan dengan masalah (kebutuhan) dalam hidup berkeluarga, bermasyarakat maupun bernegara.

Tema kajian ini sudah mulai mengulas bagaimana hukum Islam dilegislasikan dalam sistem hukum nasional, tetapi kajian ini belum memberikan ulasan tipe sistem hukum nasional yang digunakan di Indonesia. Apakah sistem negara demokratis Pancasila atau sistem negara hukum rule of law atau common law (Mahfud MD, 2010: 178). Dengan demikian, jelas kajian ini juga belum memasukkan pendekatan kajian Barat terhadap tema-tema kajian fikih ini.

Kedua, Budi Kisworo (2000) berjudul, Pajak dan Zakat dalam Perspektif Fikih. Tema kajian ini berangkat dari pandangan bahwa ada beberapa persamaan antara pajak dan zakat. Keduanya adalah pungutan yang mempunyai unsur memaksa, tetapi juga ada beberapa hal yang secara spesifik membedakan pajak dari zakat. Hasil penelitian ini menyebutkan bahwa pajak tidak bisa menggantikan kedudukan zakat, karena keduanya adalah dua hal yang berbeda walaupun ada kesamaannya, sehingga kewajiban pajak harus ditunaikan seiring dengan pelaksanaan kewajiban. Dalam masalah hukum pengenaan pajak, fikih Islam memberikan toleransi kewajiban pemungutannya dengan alasan doktrin infaq fisabilillah dan jihad dengan harta, tidak memadainya dana zakat dan adanya beberapa proyek kesejahteraan umat yang tidak bisa diambilkan dari dana zakat, kewajiban memelihara solidaritas sosial, dan beberapa kaidah umum hukum syara' berdasarkan pada maslahat. Penetapan kewajiban pajak oleh negara terhadap warganya harus memerhatikan beberapa persyaratan, di antaranya adalah dipenuhinya prinsip keadilan dan pendayagunaan untuk kemaslahatan umum. Meskipun ada upaya untuk menyatukan pelaksanaan kewajiban zakat dengan pajak, tetapi teknik operasionalnya masih memerlukan pemikiran lebih lanjut.

Dari ulasan tersebut, tema kajian ini merupakan tema kajian keislaman yang sudah diperluas dengan wacana keilmuan umum, yaitu pajak, tetapi pembahasan ini belum bisa menciptakan rumusan yang serasi dan sinergis untuk membangun wawasan fikih dalam bidang zakat dan 
pajak, sehingga kajian ini hanya memberikan rekomendasi untuk dibahas lebih lanjut jika akan disatukan antara kewajiban zakat dan pajak. Di samping itu, di sini belum ada pendekatan sains Barat yang digunakan untuk membaca wacana tentang pajak dan zakat.

Kajian ini belum memberikan ulasan bagaimana memposisikan zakat dalam konteks pajak secara setara. Hal ini berbeda dengan hasil kajian Redaksi Jaringan Islam Liberal (JIL) ketika mengupas Masdar Farid Mas'udi:Zakat Bukan Money Laundering, yang sudah mulai membangun sinergi yang lebih intensif antara masalah zakat dengan masalah pajak (Redaksi JIL, 2012).

Ketiga, karya Toha Andiko (2000) berjudul Korelasi Ijtibad dengan Maquasid al-Shari'ah. Tema kajian dari beragam ijtihad yang telah dipaparkan di atas dapat dikemukakan bahwa Maqāsid al-Shari'ah adalah tujuan utama dan terakhir dari disyariatkannya hukum Islam secara keseluruhan. Dengan berpatokan pada Maqāsid al-Sharìah, umat dapat termotivasi untuk berusaha melakukan ijtihad dalam menjawab berhagai problematika kontemporer, minimal yang menyangkut hukum praktis untuk memenuhi kebutuhan pribadi. Oleh sebab itu, pendekatan kajian ini bersifat non-mazhab dan substansial. Tema kajian menunjukkan bahwa masalah ijtihad dalam Islam mempunyai peranan dan kedudukan yang penting dalam memahami pesan-pesan dan maksud-maksud Tuhan yang tidak semuanya disebutkan dalam wahyu. Ijtihad sebagai upaya pemikiran maksimal manusia yang dikerjakan secara sungguhsungguh dilakukan untuk menemukan hukum-hukum Islam tentang berbagai masalah yang belum diatur hukumnya dan berkualitas z̧ann (Syarifuddin, 2009 dan Zahrah, 1994: 567).

Tema kajian ini menandaskan bahwa dengan mempelajari, mengetahui, dan menguasai Maqāsid al-Sharì'ah sebagai hasil kajian ulama terdahulu akan membantu setiap mujtahid dalam menemukan dan menerapkan pesan-pesan dan maksud-maksud Tuhan (Maqäsìi alSharìab) baik yang tersurat maupun yang tersirat dalam nash. Dengan pendekatan nonmazhab ini, pemahaman terhadap Maqāsid al-Sharì'ah, dapat pula mengaktualkan aturanaturan hukum Islam pada setiap waktu dann keadaan tanpa kesulitan melalui metode ijtihad tersebut (Khallaf, 1978: 56). Walaupun demikian, ulasan-ulasan ini belum menggunakan pendekatan sains terhadap tema kajian ini, misalnya teori utilitarianisme John S Mill.

Hasil wawancara dengan Moh Dahlan, salah seorang dosen Fikih Kontemporer STAIN Bengkulu, menyebutkan bahwa kategori kencederungan tema kedua yang sudah mulai memperluas wacana kajian fikihnya pada dasarnya termasuk paling dominan karena wacana 
keilmuan fikih ini lahir dari gagasan modernisasi yang disuarakan oleh A Mukti Ali dan Harun Nasution yang kemudian memengaruhi wacana keilmuan fikih murid-muridnya, termasuk seperti Toha Andiko dan Budi Kisworo yang keduanya adalah alumni Syarif Hidayatullah, sehingga kecenderungan modernisasi dari dua orang dosen ini lebih dominan walaupun tidak sampai mengintegrasikan dengan pendekatan sains Barat terhadap tema kajian fikih (wawancara dengan Moh Dahlan, dosen STAIN Bengkulu pada tanggal 7 September 2012).

Jika dianalisis dari pemikiran intelektualisme Muslim dari Azyumardi Azra, maka tema kajian fikih ini masuk kategori intelektualisme inklusif karena tema-tema kajiannya baru berusaha memadukan antara aspek-aspek keilmuan secara luas dalam bidang fikih dengan pendekatan non-mazhab. Walaupun dari sisi pendekatannya belum menggunakan kajiankajian sains Barat, tetapi dari sisi tema kajiannya sudah cukup luas dan terbuka, tetapi masih menyimpan aspek apologis jika wacana sains dihadapan dengan wacana fikih.

\section{Kecenderungan pluralis}

Tema kecenderungan kajian ketiga ini mengalami peningkatan karena tema kajian ini sangat diperlukan untuk melakukan pembaruan pemikiran fikih yang lebih progresif dan aktual di masa kini. Kecenderungan kajian ini mencantumkan tiga tema (Dahlan, 2012): Pertama, Budi Kisworo (2000) berjudul, Konsistensi dan Fleksibilitas Hukum Islam menurut Hazairin. Tema kajian ini memotret pemikiran Hazairin sebagai seorang pakar hukum yang melihat hukum Islam secara konsisten dan fleksibel. Sifat konsistensi hukum Islam, menurutnya, pada aspek ibadah, sehingga tidak perlu dilakukan pembaharuan. Fikih klasik telah cukup memberikan penjelasan lengkap bagaimana seseorang harus beribadah kepada Tuhannya. Adapun masalah hukum Islam yang berhubungan dengan kemasyarakatan masih memerlukan penjelasan lebih lanjut agar dapat dilaksanakan oleh masyarakat modern. Hukum-hukum yang terdapat dalam fiqih tradisional banyak yang tidak sesuai dengan situasi dan kondisi masyarakat sekarang, sehingga diperlukan reinterpretasi terhadap dalil-dalil syara' dengan membaca kondisi masyarakat setempat agar tujuan hukum Islam itu dapat terwujud. Dalam wacana keilmuan hukum di tingkat internasional, pendapat Hazairin ini bukan hal baru, karena gagasan itu telah banyak dikemukakan oleh para pemikir Islam di Mesir, Turki, India, dan Pakistan, 
tetapi dalam konteks keindonesiaan, gagasan ini dapat dikatakan baru, karena sebelumnya belum ada tokoh yang menggagas tentang hal itu. Ia menggagas perlunya fiqih Indonesia, tetapi gagasannya baru dikemukakan tahun 1963, jauh setelah Hazairin mengemukakan pemikiran pembaruannya. Apalagi kalau dibaca latar belakang disiplin ilmu yang dimiliki oleh Hazairin,-sebagai pakar hukum adat- maka semakin terasa betapa pemikirannya telah mencoba menggunakan kajian sains Barat terhadap kajian hukum Islam, terutama dalam bidang waris Islam di Indonesia.

Tema kajian Budi Kisworo ini telah mengulas wacana fikih yang bersinegri dengan hukum adat yang telah digagas oleh Hazairin. Oleh sebab itu, model kajian seperti ini dapat dikembangkan untuk membangun fikih keindonesiaan yang menjadi gagasan Hazairin, sehingga fikih bersifat empiris-sosiologis.

Kedua, karya Ujang Mahadi (2000) berjudul Pelaksanaan Zakat Profesi di Kalangan Pegawai Negeri Sipil (PNS). Tema kajian ini mengulas surat al-Baqarah ayat 267 dan asas keadilan dengan dasar pendapat para fukaha' yang menyatakan bahwa berbagai jenis kegiatan atau usaha manusia yang sah dan mendatangkan penghasilan (termasuk Pegawai Negeri Sipil) yang penghasilannya telah mencapai nishab (94 gram emas) dan haul (masa setahun), maka orang tersebut wajib mengeluarkan zakat dua setengah persen. Zakat dapat dikeluarkan setelah masa haulnya, kecuali ada kehawatiran penghasilannya terbelanjakan apabila menunggu sampai masa tahunnya, maka dapat dikeluarkan setiap bulan atau pada saat penghasilan itu diperoleh. Tema kajian ini menetapkan bahwa zakat profesi Pegawai Negeri Sipil dapat dikeluarkan pada saat menerima gaji. Dengan teori fikih tesebut, penulis ini menggunakannya untuk membaca fenomena kesadaran zakat profesi bagi PNS di Kota Bengkulu yang disimpulkan masih tergolong rendah, hal ini disebabkan oleh beberapa alasan: terbatasnya pengetahuan tentang zakat profesi; dan gaji yang diterima setiap bulan sudah tidak mencukupi nishab karena potongan dari pinjamannya pada Bank, Koperasi maupun lainnya.

Dengan demikian, tema kajian ini tidak hanya diperluas, tetapi juga konsep-konsep fikih itu digunakan untuk membaca fenomena empiris praktis. Dari segi tema bahasan juga sudah mengikutkan pendekatan sains Barat berupa ulasan-ulasan aspek ekonomi dalam pelaksanaan zakat profesi. Jika dianalisis dengan teori sibernetika Talcott Parsons (Goesniadhie, 2010: 98 100), konsep pelaskanaan zakat profesi ini dapat dinyatakan bahwa aspek ekonomi 
menentukan aspek budaya termasuk di dalamnya aturan hukum agama, fikih.

Ketiga, karya Rohimin (2000) berjudul Dinamika Hukum Islam pada Masa Pemerintahan Orde Baru. Tema kajian ini mengulas dinamika hukum Islam di masa Orde Baru. Pada masa pemerintahan Orde Baru, hukum Islam mendapat peluang untuk diimplementasikan sebagai sistem hukum. Hal ini terjadi karena hukum Islam telah dijadikan sebagai landasan spiritual, moral dan etik. Secara konstitusional, umat Islam memiliki peluang untuk merumuskan hukum Islam menjadi hukum nasional melalui lembaga legislatif, pendidikan, dakwah dan melalui yudikatif. Kebijakan politik hukum pemerintah Orde Baru dalam memberlakukan hukum Islam sebagai salah satu sistem hukum dapat dibuktikan melalui berbagai produk hukum dan undang-undang nasional yang diberlakukan pada umat Islam Indonesia. Menurut Anderson, selama Orde Baru, ada tiga undang-undang yang merupakan tonggak penting bagi umat Islam, yaitu Undang-Undang Nomor 14 Tahun 1970, Undang-Undang Nomor I Tahun 1974 den Undang-Undang Nomor 7 Tahun 1989.

Dari sini dapat dipahami bahwa tema kajian ini berusaha membaca perkembangan historis hukum Islam semasa Orde Baru melalui analisis proses pengundangan dalam sistem hukum positif yang menunjukkan bahwa pemerintah Orde Baru telah mengakomodir desakandesakan umat Islam dengan mengundangkan hukum Islam dalam sistem hukum nasional melalui produk-produk hukum yang berkaitan dengan materi hukum Islam tersebut.

Jika dianalisis dari tipologi intelektualisme Muslim yang disuguhkan oleh Azyumardi Azra, maka tema kajian fikih ini dapat dimasukkan dalam kategori intelektualisme Muslim pluralis karena tema-tema kajiannya sudah menggunakan pendekatan sains Barat kontemporer, disamping aspek-aspek keluasan tema kajiannya, sehingga tidak ada aspek apologis dalam kajian fikih ini.

Menurut Suwarjin, karya-karya dosen yang memiliki karakter ketiga ini pada dasarnya sedang digemari dan dikembangkan karena realitas kondisi kekinian menghendaki adanya pemaduan tema-tema kajian fikih dengan tema-tema kajian hukum atau sains pada umumnya. Munculnya perbankan syariah, bukan fikih muamalah, menjadi indikator bahwa betapa tema-tema wacana fikih masa kini harus bersinergi dengan tema-tema sains, dalam hal ini perbankan konvensional, misalnya (wawancara dengan Suwarjin, dosen STAIN Bengkulu pada tanggal 9 September 2012). 


\section{Penutup}

Latarbelakang lahirnya dan upaya pembangunan kajian keilmuan fikih yang dilakukan oleh dosen STAIN Bengkulu dapat diklasifikasIkan menjadi tiga kencenderngan pendekatan dan tema. Pertama, kencenderungan pendekatan dan tema kajian keilmuanya yang normatif. Hal ini tidak lepas dari pengaruh tradisi kajian fikih di lingkungan PTAI pada masa lampau yang normatif, sehingga wacana keilmuan fikih dosen STAIN Bengkulu banyak dibangun berdasarkan orientasi normatif.

Kedua, kecenderungan pendekatan dan tema yang kedua ini telah memperluas wacana kajian keilmuan fikihnya yang dipengaruhi oleh gagasan modernisasi A Mukti Ali dan Harun Nasution yang kemudian mempengaruhi wacana keilmuan fikih murid-muridnya yang menjadi dosen di PTAI, termasuk di STAIN Bengkulu. Wacana keilmuan fiqh ini dibangun dengan melakukan perluasan terhadap kajian keilmuan fikih berdasarkan perkembangan keilmuan sains pada umumnya.

Ketiga, kecenderungan pendekatan dan tema kajian yang ketiga ini pada dasarnya sedang digemari dan dikembangkan karena kondisi kekinian menghendaki adanya pemaduan pendekatan dan tema kajian kelimuan fikih dengan perkembangan sains pada umumnya. Lahirnya perbankan syariah, bukan fikih muamalah, menjadi indikator bahwa adanya perkembangan yang pesat dalam hal pendekatan dan tema-tema kelimuan fikih pada masa kini. Wacana keilmuan fikih ini dibangun dengan melakukan integrasi antara kajian keilmuan fikih dengan keilmuan sains pada umumnya.

Adapun keterbatasan kajian keilmuan fikih ini belum memberikan gambaran yang representatif bagi tipologi pengembangan keilmuan fikih di Perguruan Tinggi Agama pada umumnya, karena kajian keilmuan fikih ini hanya terbatas pada lingkup keilmuan fikih bagi para dosen STAIN Bengkulu, sehingga hasil kajian ini tidak bisa digeneralisasi.

\section{Daftar pustaka}

Abdullah, M. Amin. Studi Agama: Normativitas dan Historisitas. Yogyakarta: Pustaka Pelajar,1996. Abu Zahrah, Muhammad, Ușül al-Fiqh. terj. Saefullah Ma’sum. Jakarta: Pustaka Firdaus, 1994. 
ljtihad, Jurnal Wacana Hukum Islam dan Kemanusiaan, Vol. 12, No. 2, Desember 2012: 237-258

Aibak, Kutbuddin. Kajian Fikih Kontemporer. Yogyakarta: Teras, 2009.

Anderson, James Norman Dalrymple. Islamic Law in the Modern World. diterjemahkan oleh Machnun Husein dengan judul, Hukum Islam di Dunia Modern. Surabaya: CV. Amrpress, 1991.

Andiko, Toha, "Korelasi Ijtihad dengan Maqāsid al-Sharī'ah”, Jurnal Madania, Vol. 3 , No. 5 (Desember 2000).

Azra, Azyumardi. Pendidikan Islam: Tradisi dan Modernisasi Meniju Milenium Baru. Jakarta: Logos, 1999.

Bakar, Osman. Taubid dan Sains, Esai-Esai tentang Sejarah dan Filsafat Sains Islam. terj. Yuliani Liputo, Bandung: Pustaka Hidayah, 1994.

Bowen, John R. Islam, Law and Equality in Indonesia: An Introduction of Public Reasoning. Cambridge: Cambridge University Press, 2003.

Darmadi, Dadi, "IAIN dalam Wacana Intelektual Islam Indonesia", http:// www.ditpertais.net/artikel/dadi01.asp diakses 12 September 2012.

Denzin, Norman K, dan Yvonnas S Lincoln. Handbook of Qualitative Research. terj. Dariyanto dkk. Yogyakarta: Pustaka Pelajar, 2009.

Goesniadhie, Kusnu. Harmonisasi Sistem Hukum: Mewujudkan Tata Pemerintahan yang Baik. Malang: Nasa Media, 2010.

Hidayat, Komaruddin, dan Ahmad Gus AF. Passing Over Melintasi Batas Agama. Jakarta: Paramadina dan Gramedia, 2001.

Khallaf, 'Abd al-Wahhab. Tlm Ușūl al-Fiqh. Kairo: Dār al-Qalam, 1978.

Khoiri, Alwan, "Perkawinan Antaragama: Perspektif Hukum Islam”, Jurnal Madania, Vol. III, No 4 (Juni 2000).

Kisworo, Budi, “Konsistensi dan Fleksibilitas Hukum Islam menurut Hazairin”, Jurnal Madania, Vol. III, No 4 (Juni 2000).

Kisworo, Budi, "Pajak dan Zakat dalam Perspektif Fikih", Jurnal Madania, Vol. 3, No. 5 (Desember 2000). 
Lubis, Nur A. Fadhil. Pengembangan Studi Hukum Islam Di LAIN, http:/ /www.ditpertais.net/ artikel/fadil01.asp

Mahadi, Ujang, "Pelaksanaan Zakat Profesi di Kalangan Pegawai Negeri Sipil (PNS)", Jurnal Madania, Vol. 3, No. 5 (Desember 2000).

Mahfud MD, Moh. Membangun Politik Hukum, Menegakean Konstitusi. Jakarta: Rajawali Pers, 2010.

Nurbaiti, "Implikasi Sunnah Tasyri'iyyah dan Ghairu Tasyri'iyyah", JurnalMadania, Vol. 11, Nomor 1 (Juni 2007).

Rahim, Rahimin Affandi Abd., dkk, "Konsep Fiqah Malaysia dalam Perundangan Islam: Satu Pengenalan/The Concept of Malaysian Fiqah in Islamic Law: An Introduction”, Jurnal Kajian Malaysia, Vol. 28, No. 2 (2010).

Rani, Yen Fikri, "Rekonstruksi Tasawuf dan Syariat: Sebuah Pemikiran Ahmad Sirhindi”, Jurnal Madania, Vol. 11, No. 1 (Juni 2007).

Redaksi Jaringan Islam Liberal (JIL), Masdar Farid Mas'udi: Zakat Bukan Money Laundering, http://islamlib.com/id/artikel/zakat-bukan-money-laundering, diaskes 12 September 2012.

Rohimin, "Dinamika Hukum Islam pada Masa Pemerintahan Orde Baru", JurnalMadania, Vol. III, No 4 (Juni 2000).

Shihab, Alwi. Islam Inklusif: Menuju Sikap Terbuka dalam Beragama. Bandung: Mizan, 2005.

Siraj, A Maltuf. Pembaruan Hukum Islam: Telaah Kompilasi Hukum Islam. Yogyakarta: Pustaka Ilmu, 2012.

Siswanto Masruri. Bagaimana Menulis Karya (Artikel) Ilmiab? http:// siswantomasruri.wordpress.com/2010/11/18/bagaimana-menulis-karya-artikelilmiah/\#more-189.

Suprayogo, Imam, "Kajian Ilmu Agama di Tengah Kesemarakan PTAIN", http:// www.facebook.com/notes/imam-suprayogo-satu/kajian-ilmu-agama-di-tengahkesemarakan-ptain/10150664395878880, diakses 14 Maret 2012. 
ljtihad, Jurnal Wacana Hukum Islam dan Kemanusiaan, Vol. 12, No. 2, Desember 2012: 237-258

Syamsuddin, Din, "Usaha Pencarian konsep Negara dalam sejarah Pemikiran Politik Islam" dalam Abu Zahra (ed.), Politik. Demi Tuban: Nasionalisme Religius di Indonesia. Jakarta: Pustaka Hidayah, 1999.

Syarifuddin, Amir. UshulFikib 1. Jakarta: Kencana, 2009

Syarnubie, "Rekonstruksi Pemikiran Format Hukum Islam”, Jurnal Madania Vol. III, No. 4 (Juni 2000).

Al-Syirazi, Abu Ishaq Ibrahim Ibn Ali Ibn Yusuf. Al-Muhadhdhab fi Fiqh Madhhab al-Imām alShafi i. Beirut: Dar al-Fikr, 1994.

Zainuddin. Fath al-Müin. Semarang: Taha Putra, t.th.

Zakaria, Gamal Abdul Nasir Hj, dan Salwa Dato Hj Mahalle, "The Role of I.A.I.N. In The Education System Reform of the "Madrasah" dalam American International Journal of Contemporary Research, Vol. 2, No. 5 (May 2012).

Zubaedi, Zulkarnain S, dan Moh Dahlan. Studi terbadap Karya-Karya Dosen STAIN Bengkulu Tabun 2000-2010. Jakarta: Kerjasama Balitbang dan Diklat Kemenag RI dengan STAIN Bengkulu, 2012.

Wawancara:

Rohimin, Prof. Dr., M.Ag., guru besar STAIN Bengkulu pada tanggal 7 September 2012.

Moh Dahlan, Dr., M.Ag., dosen STAIN Bengkulu pada tanggal 7 September 2012.

Suwarjin, M.A., dosen STAIN Bengkulu pada tanggal 9 September 2012. 